\title{
Influence of folic acid supplements on the carry-over of folates from the sow to the piglet
}

\author{
B. Barkow ${ }^{1}$ J. J. Matte ${ }^{2}$, H. Böhme ${ }^{1}$ and G. Flachowsky ${ }^{1 *}$ \\ ${ }^{1}$ Institute of Animal Nutrition, Federal Agricultural Research Centre, Bundesallee 50, 38116 Braunschweig, Germany \\ ${ }^{2}$ Dairy and Swine Research and Development Centre, Lennoxville (Quebec), Canada J1M 1Z3
}

(Received 12 January 2000 - Revised 3 August 2000 - Accepted 13 September 2000)

\begin{abstract}
This experiment aimed to investigate the influence of folic acid supplements on the carry-over of folates from the sow to the fetus during late gestation and to the suckling piglet. Two groups of sixteen German Landrace sows received, during gestation and lactation, a diet supplemented with either 0 or $10 \mathrm{mg}$ folic acid/ $\mathrm{kg}$. Increased folic acid concentrations in the serum of sows were detected only at the end of gestation (day 100) and at the end of lactation (day 28). The supplementation with folic acid to the sows' diet improved the folic acid supply of the fetus compared with unsupplemented controls; values were respectively $92.6 v .56 \cdot 2 \mathrm{nmol}$ folates/l serum in newborn piglets and $171.9 v .76 .3 \mu \mathrm{mol}$ folates/g fresh liver in stillborn piglets $(P<0.05)$. Folate concentrations in colostrum and milk (day 28) were $3 \cdot 6$ - and $5 \cdot 0$-times higher in supplemented than unsupplemented sows. This treatment effect was also reflected in the serum of piglets until weaning. Therefore, the folic acid supply for the suckling piglet is dependent mainly upon the carry-over of maternal folates via colostrum and milk.
\end{abstract}

Folic acid: Sow: Piglet

Folic acid is of great importance for the synthesis of DNA and is involved in several reactions of the amino acid metabolism (Bässler, 1997). Therefore, active proliferative cells such as those from the placenta, embryo, fetus or the newborn increase the folic acid requirements of the dam.

Matte et al. (1993) and Duquette et al. (1997) showed that folates can cross the placental barrier in swine. Indeed, folic acid supplements to gilts tended to increase the fetal folates on day 50 of gestation (Matte et al. 1993) and the folate content in uterine secretions on day 12 of gestation (Duquette et al. 1997). The uterine transfer of folates in multiparous sows during early gestation was less apparent (Matte et al. 1996). In addition, little is known about the folate supply status of newborn piglets before the first ingestion of colostrum and whether it is possible to increase this status by supplementing the sow with folic acid during gestation. Furthermore, little is known about the folate content of colostrum and on the effect of dietary supply of folic acid during gestation on folate transfer to colostrum. Therefore, the aim of the present experiment was to evaluate the effect of dietary supplements of folic acid on the carry-over of folates to the fetus during gestation and to the suckling piglet during lactation.

\section{Material and methods \\ Animals and treatments}

A total of thirty-two German Landrace sows were randomly assigned to two different treatments (twelve reproductive cycles of gilts and thirty of multiparous sows were used in the experiment). At mating the average body weight of gilts was $123 \mathrm{~kg}$ and that of multiparous sows was $171 \mathrm{~kg}$. The first group received a basal diet during gestation and lactation (described in Table 1) according to the recommendations of the German Society of Nutrition Physiology (1987). The second group was fed the basal diet supplemented with $10 \mathrm{mg}$ folic acid/ $\mathrm{kg}$ feed. All sows were mated with Pietrain boars. Pregnancy was verified by ultrasonic examination at day 30 post-mating. During gestation, all sows were kept in a group housing with individual feeding. At about day 110 of gestation the animals were transferred into nursing cages in which they stayed during the $28 \mathrm{~d}$ lactation. All stables were without bedding material. Immediately after birth all piglets were weighed individually. On day 2 of life they received an intramuscular injection of $200 \mathrm{mg} \mathrm{Fe}^{3+}$ as $\mathrm{Fe}$ dextran.

Gestating sows were fed $2.3 \mathrm{~kg}$ gestating diet (Table 1)

\footnotetext{
* Corresponding author: Professor G. Flachowsky, fax +49 531596 376, email Herweg@te.fal.de
} 
Table 1. Composition of the gestation and lactation basal diet and of the diet for suckling pigs (Mean values and standard deviations)

\begin{tabular}{|c|c|c|c|c|c|c|}
\hline & \multicolumn{2}{|c|}{ Gestation diet } & \multicolumn{2}{|c|}{ Lactation diet } & \multicolumn{2}{|c|}{ Diet for suckling pigs } \\
\hline & Mean & SD & Mean & SD & Mean & SD \\
\hline \multicolumn{7}{|l|}{ Ingredient $(\mathrm{g} / \mathrm{kg})$} \\
\hline Barley & $573 \cdot 0$ & & $330 \cdot 0$ & & $440 \cdot 0$ & \\
\hline Wheat & - & & 332.5 & & $280 \cdot 0$ & \\
\hline Oats & $200 \cdot 0$ & & $100 \cdot 0$ & & - & \\
\hline Wheat bran & $140 \cdot 0$ & & - & & - & \\
\hline Soyabean meal & $50 \cdot 0$ & & $180 \cdot 0$ & & $190 \cdot 0$ & \\
\hline Soyabean oil & $10 \cdot 0$ & & $20 \cdot 0$ & & $10 \cdot 0$ & \\
\hline Dicalcium phosphate & - & & 3.5 & & - & \\
\hline Minerals and vitamins* & $27 \cdot 0$ & & $30 \cdot 0$ & & - & \\
\hline Minerals and vitamins $\dagger$ & - & & - & & $20 \cdot 0$ & \\
\hline Lysine monochloride & - & & $2 \cdot 0$ & & - & \\
\hline Fishmeal & - & & - & & $60 \cdot 0$ & \\
\hline Sodium chloride & - & & $2 \cdot 0$ & & - & \\
\hline \multicolumn{7}{|l|}{ Analysed nutrients $\ddagger$} \\
\hline DM $(g / k g)$ & $884 \cdot 1$ & $7 \cdot 3$ & $883 \cdot 4$ & $6 \cdot 3$ & $873 \cdot 2$ & $6 \cdot 4$ \\
\hline Organic matter ( $\mathrm{g} / \mathrm{kg} \mathrm{DM}$ ) & $942 \cdot 0$ & 1.4 & $936 \cdot 5$ & $2 \cdot 1$ & $940 \cdot 9$ & 1.5 \\
\hline Crude protein ( $\mathrm{g} / \mathrm{kg} \mathrm{DM})$ & $146 \cdot 3$ & $5 \cdot 2$ & $189 \cdot 6$ & 3.6 & 230.9 & $6 \cdot 0$ \\
\hline Diethyl ether ( $\mathrm{g} / \mathrm{kg} \mathrm{DM})$ & $32 \cdot 8$ & 3.7 & 33.6 & $5 \cdot 0$ & $32 \cdot 2$ & $4 \cdot 2$ \\
\hline Crude fibre ( $g / \mathrm{kg} \mathrm{DM})$ & 74.9 & 3.4 & $52 \cdot 3$ & 4.4 & $48 \cdot 3$ & $4 \cdot 1$ \\
\hline $\mathrm{N}$-free extracts (g/kg DM) & $688 \cdot 0$ & 5.5 & $661 \cdot 0$ & 8.5 & 629.5 & $5 \cdot 6$ \\
\hline Starch (g/kg DM) & $441 \cdot 3$ & $12 \cdot 6$ & $466 \cdot 4$ & $7 \cdot 6$ & $449 \cdot 6$ & $10 \cdot 3$ \\
\hline Sugar (g/kg DM) & $31 \cdot 7$ & 1.6 & 38.4 & 2.9 & $39 \cdot 0$ & $2 \cdot 3$ \\
\hline Metabolisable energy (MJ/kg DM)§ & $13 \cdot 14$ & & $14 \cdot 61$ & & $14 \cdot 89$ & \\
\hline \multicolumn{7}{|l|}{ Folic acid } \\
\hline Calculated $(\mathrm{mg} / \mathrm{kg}) \|$ & 0.71 & & 0.48 & & NA & \\
\hline Analysed $(\mathrm{mg} / \mathrm{kg}) \emptyset$ & 0.62 & 0.07 & 0.69 & 0.09 & NA & \\
\hline $\mathrm{Ca}$ & 9.39 & 1.08 & 11.44 & 0.85 & $9 \cdot 41$ & 0.83 \\
\hline $\mathrm{P}$ & $7 \cdot 11$ & 0.15 & 6.31 & 0.27 & 8.03 & 0.20 \\
\hline
\end{tabular}

NA, not analysed.

* Composition (per kg): Ca 240 g, P 60 g, Na 55 g, Mg 10 g, Fe 5500 mg, Zn 4000 mg, Mn 2500 mg, Cu 950 mg, I 40 mg, Se 13 mg, vitamin A 120 mg cholecalciferol $1 \mathrm{mg}$, vitamin E $1200 \mathrm{mg}$, menadione $40 \mathrm{mg}$, thiamin $40 \mathrm{mg}$, riboflavin $125 \mathrm{mg}$, vitamin $\mathrm{B}_{6} 80 \mathrm{mg}$, vitamin $\mathrm{B}_{12} 600 \mu \mathrm{g}$, pantothenic acid $245 \mathrm{mg}$, nicotinic acid $500 \mathrm{mg}$, choline chloride $2400 \mathrm{mg}$.

† Composition (per kg): Ca 220 g, P 80 g, Na 60 g, Mg 5 g, Fe 5300 mg, Zn 5000 mg, Mn 2400 mg, Cu 1000 mg, I 80 mg, Co 16.5 mg, Se 16.5 mg, vitamin A $180 \mathrm{mg}$, cholecaliferol $1.5 \mathrm{mg}$, vitamin E $1350 \mathrm{mg}$, menadione $40 \mathrm{mg}$, thiamin $60 \mathrm{mg}$, riboflavin $150 \mathrm{mg}$, vitamin $\mathrm{B}_{6} 100 \mathrm{mg}$, vitamin $\mathrm{B}_{12} 1200 \mu \mathrm{g}$, folic acid $15 \mathrm{mg}$, nicotinic acid $600 \mathrm{mg}$, panthotenic acid $250 \mathrm{mg}$, choline chloride $5000 \mathrm{mg}$.

‡ For gestation diet, lactation diet and diet for suckling pigs $n 11, n 21$ and $n 4$ respectively.

$\S$ Bacterial fermentable substance, corrected metabolisable energy (German Society of Nutrition Physiology, 1987).

II According to the National Research Council (1998).

ๆ For gestation diet and lactation diet $n 15$ and $n 9$, respectively.

from weaning until day 84 of gestation and $2 \cdot 3 \mathrm{~kg}$ lactation diet from day 85 to 110 of gestation (Table 1) two times per d 07.00 and 14.00 hours six d per week and once per d on Sundays. Just before the expected farrowing date $(3 \mathrm{~d})$ the daily amount of feed was gradually reduced to 1.5 or $1 \mathrm{~kg}$. After farrowing the amount of lactation diet provided to the sows per $\mathrm{d}$ was increased during the first $5 \mathrm{~d}$ of lactation to a total of $2.3 \mathrm{~kg}$ plus $0.3 \mathrm{~kg}$ for every piglet. Fresh water was provided ad libitum. The piglets received a diet for suckling pigs (Table 1) ad libitum (maximum consumption 5-7 g/piglet per $d$ in the 4th week of the suckling period).

\section{Folic acid supplements}

Two different types of supplemented feed were prepared which were always used within 6 weeks after preparation. For the supplementation given during the period between weaning and day 84 of gestation, folic acid was mixed into the basal gestation diet to produce a premix which contained $230 \mathrm{mg}$ folic acid/kg premix (analytical value of 181 (SD 39.2; $n$ 12). The premix (100 g) was given as a 'top-dressing' to $2.2 \mathrm{~kg}$ of gestation diet for a daily allowance of $2.3 \mathrm{~kg}$ of feed per sow. The lactation diet was supplemented with folic acid to provide a level of $10 \mathrm{mg} / \mathrm{kg}$ feed.

\section{Blood sampling}

During gestation and lactation, blood samples were taken from sows at 07.00 hours immediately before feeding on day 30, 60 and 100 of gestation and on day 28 of lactation (plus or minus $1 \mathrm{~d}$ ). About $9 \mathrm{ml}$ blood was drawn from the jugular vein into sterile blood collection tubes (Monovetten, Sarstedt, Berlin, Germany).

From six litters in each treatment, three newborn piglets were chosen for blood sampling immediately after birth and before the first ingestion of colostrum. Their body weight was as close as possible to the average of the litter. For every litter, a group of four piglets of an average body weight similar to that of the whole litter were chosen for blood collection on day 2, 14 and $28 \mathrm{~d}$ of age. For blood sampling, piglets were manually restrained and $3 \mathrm{ml}$ blood was drawn from newborn and 2 d-old piglets and $5 \mathrm{ml}$ from older ones by puncture of the $v$. jugularis or $v$. cava cranialis.

Blood samples of dams and piglets were allowed to clot 
in the dark at room temperature for 45-60 min, centrifuged for $30 \mathrm{~min}$ at $4^{\circ} \mathrm{C}$ and $3000 \mathrm{~g}$ and transferred into polypropylene tubes for storage at $-20^{\circ} \mathrm{C}$.

\section{Milk sampling}

During parturition or within $12 \mathrm{~h}$ post partum, samples of colostrum $(40-70 \mathrm{ml})$ were obtained from sows by hand milking after intramuscular injection of 30-40 IU oxytocin. A similar amount of colostrum was taken from every lactating mammary complex. Milk samples were taken by the same procedure on the 28th day of lactation.

\section{Liver samples}

The livers from a total of seven stillborn piglets were used for hepatic folate determination. Those piglets were close to the average birth weight and showed no macroscopic variation of anatomical abnormalities. Livers were removed immediately after birth and kept frozen at $-20^{\circ} \mathrm{C}$ until analysis.

\section{Measurements}

Dietary folates were analysed in duplicate on three hydrolysates of the same sample with commercial radioassay kits using $\left[{ }^{125} \mathrm{I}\right]$-labelled pteroylglutamic acid (QuantaphaseII Folate ${ }^{\circledR}$; BioRad, Munich, Germany) as described by Matte et al. (1990). Preparation of samples before the assay was done according to a method adapted from Cerna \& Kas (1983). In a $50 \mathrm{ml}$ conical tube, $0 \cdot 1 \mathrm{~g}$ feed was mixed with $12 \mathrm{ml}$ McIlvain buffer $(284 \mathrm{~g}$ $\mathrm{Na}_{2} \mathrm{HPO} / 1,500 \mathrm{mg}$ ascorbic acid/l, add distilled water, adjust $\mathrm{pH}$ to 4.6 with $3.3 \mathrm{M}-\mathrm{NaOH}$ and made up to 1 litre with distilled water) and autoclaved for $10 \mathrm{~min}$ at $121^{\circ} \mathrm{C}$. The $\mathrm{pH}$ was adjusted to 7.0 with $3.3 \mathrm{M} \mathrm{NaOH}$ and the volume made up $20 \mathrm{ml}$ with distilled water. The solution was vortexed and then centrifuged at $3000 \mathrm{~g}$ for $10 \mathrm{~min}$. The supernatant fraction was used for folates determination. The effect of chicken pancreas conjugase (transformation of polyglutamates to monoglutamates) on concentrations of folates was tested using the method described by Cerna \& Kas (1983). No effect of conjugase was noted on concentrations of dietary folates, and subsequently all assays were run without pretreatment with conjugase. The results seem to confirm previous observations (Rothenberg et al. 1974) on the versatility of the radioassay technique for both polyglutamates and monoglutamates. Results of parallelism tests were satisfactory $(\mathrm{CV}<10 \%)$ between 0 and $5 \mathrm{mg} / \mathrm{kg}$ and inter-assays CV $9.1 \%$. Recovery tests from a simulated mixing in laboratory gave a mean value of $94.2 \%$. Serum folates were analysed in duplicate with commercial radioassay kits using [125I]-labelled pteroylglutamic acid (QuantaphaseII Folate ${ }^{\circledR}$, BioRad) validated for swine serum (Tremblay et al. 1986). Prior to analysis, samples were diluted 1:71:16 with saline $(9 \mathrm{~g} \mathrm{NaCl} / \mathrm{l})$ depending upon the expected amount of serum folates. Results of parallelism tests were satisfactory $(\mathrm{CV}<10 \%)$ and recovery tests gave a mean of $103 \%$. Milk samples were prepared before determination in duplicate by the commercial radioassay kits
(QuantaphaseII Folate ${ }^{\circledR}$, BioRad) according to Matte \& Girard (1989). In a conical tube for high-speed centrifugation the samples were mixed 1:1 (samples from control sows) or 1:10 (supplemented sows) with phosphate buffer (8.71 $\mathrm{g} \mathrm{K}_{2} \mathrm{HPO}_{4} / 1,2 \mathrm{~g}$ ascorbic acid/l, add bidistilled water, adjust $\mathrm{pH}$ to 7.8 with $\mathrm{NaOH}$ ). After being covered with $\mathrm{Al}$ foil, samples were put into boiling water for $10 \mathrm{~min}$, cooled in ice-cold water, and centrifuged at $20000 \mathrm{~g}$ for $20 \mathrm{~min}$. The supernatant fraction was used for folate analysis. No effect of chicken pancreas conjugase on the concentration of folates determined could be observed. Consequently, no conjugase was used for the assays. Results of parallelism tests were satisfactory $(\mathrm{CV}<10 \%)$. Recovery tests from a simulated mixing gave a mean value $103.5 \%$ and the inter-assay CV was $4.6 \%$. Liver samples were analysed according to Dumoulin et al. (1991). In a $50 \mathrm{ml}$ conical tube, $4 \mathrm{ml}$ ice-cooled buffer ( $0.5 \mathrm{~mm}$-citric acid monohydrate $+1 \mathrm{mM}$-disodiumphosphate, $\mathrm{pH} 5 \cdot 5$ ) and $1 \mathrm{~g}$ frozen liver sample were mixed and homogenised. A portion of this mixture $(300 \mu \mathrm{l})$ was again mixed with $4 \mathrm{ml}$ ascorbic acid (10 g/l, pH 6.0) in another conical tube for high-speed centrifugation. Afterwards, the sample was incubated at $75^{\circ} \mathrm{C}$ for $30 \mathrm{~min}$, cooled in ice-cold water and centrifuged at $10000 \mathrm{~g}$ for $10 \mathrm{~min}$. A portion of the supernatant $(1 \mathrm{ml})$ was mixed with $200 \mu \mathrm{l}$ chicken pancreas conjugase and $800 \mu \mathrm{l}$ ascorbic acid $(0 \cdot 01 \mathrm{~g} / \mathrm{l})$ and incubated at $37^{\circ} \mathrm{C}$ for $5 \mathrm{~h}$. A portion of this final solution $(200 \mu \mathrm{l})$ was used for determination by QuantaphaseII Folate ${ }^{\circledR}$ (BioRad). Results of parallelism tests were satisfactory $(\mathrm{CV}<10 \%)$. Recovery tests gave a mean of $105.9 \%$ and the interassays $\mathrm{CV}$ was $3.9 \%$.

\section{Statistical analysis}

Student's $t$ test was used to analyse the influence of the folic acid supplements on the concentration of folates in the several tissues. Data concerning the changes of folate concentrations during a special period were analysed for each single group using the General Linear Models procedure of $\mathrm{SAS}^{\circledR}$ (6.12 for Windows ${ }^{\circledR}$; Statistical Analysis Systems Inc., Cary, NC, USA). GLM procedure was also used to evaluate the interaction between the number of parities on the serum folate concentration in sows.

\section{Results}

Serum folate status of sows during gestation and lactation

Serum folates in unsupplemented controls tended $(P=$ $0.063)$ to decrease from day 30 to day 60 of gestation (Table 2). Subsequently the concentration of folates remained stable until day 100 of gestation and decreased slightly but not significantly from day 100 of gestation to the end of lactation. In the group supplemented with folic acid, there was no effect $(P=0 \cdot 24)$ of the stage of gestation or lactation on the serum folate concentrations (Table 2). Serum concentration of folates were higher $(P=$ $0.03)$ in treated sows than in controls on day 100 of gestation and day 28 of lactation (Table 2). 
Table 2. Concentration of serum folates of sows during gestation and lactation according to the treatments

(Mean values and standard deviations)

\begin{tabular}{lcccccc}
\hline \multirow{2}{*}{ Treatment } & \multicolumn{3}{c}{ Control } & & \multirow{2}{*}{$10 \mathrm{mg}$ folic acid/kg feed* } \\
\cline { 3 - 4 } \cline { 6 - 7 } & $n$ & Mean & SD & & Mean & SD \\
\hline Day 30 of gestation & 19 & $136^{\mathrm{a}}$ & 43.5 & & $141^{\mathrm{a}}$ & 34.4 \\
Day 60 of gestation & 21 & $102^{\mathrm{ab}}$ & 38.3 & & $112^{\mathrm{a}}$ & 29.2 \\
Day 100 of gestation & 24 & $104^{\mathrm{Aab}}$ & 37.4 & & $140^{\mathrm{Ba}}$ & 38.5 \\
Day 28 of lactation & 25 & $92.9^{\mathrm{Ab}}$ & 31.5 & & $133^{\mathrm{Ba}}$ & 49.4 \\
\hline
\end{tabular}

$\mathrm{A}, \mathrm{B}$ Mean values within a row with unlike superscript letters were significantly different $(P<0.05)$

${ }^{a, b}$ Mean values within a column with unlike superscript letters were significantly different $(P<0.05)$.

* Gestation and lactation diet of sows. For details of diets, see Table 1.

\section{Folates in colostrum and milk of sows}

The concentration of folates in colostrum are shown in Table 3. These concentrations were 3-4 times higher $(P<$ $0.05)$ than the folate concentration in the milk at the end of lactation in both controls and supplemented sows respectively. Nevertheless, milk and colostrum folates were higher $(P<0.05)$ in supplemented sows than in controls.

The concentration of colostral : serum folates on day 100 of gestation was 1:1 and 2.5:1 in controls and treated sows respectively. On day 28 of lactation, the ratio of the concentration of milk to serum folates was $1: 3$ and $1 \cdot 1: 1$ in controls and treated sows respectively.

\section{Serum and liver folates of piglets}

The serum concentration of folates in newborn piglets was higher in treated than in controls before the first ingestion of colostrum (Table 4). The treatment effects on folate concentration in colostrum are reflected on the concentration of serum folates of piglets at 2 days of age. At birth, the folate concentration in the serum of the piglets was only half of the concentration detected in the serum of their dams on day 100 of gestation. However, at 28 days of lactation, serum folate concentration in piglets was 1.5 times and $2 \cdot 1$ times higher than the concentration of their dams' serum in controls and treated sows, respectively. The concentration of liver folates was at least doubled (172 v. $76.3 \mathrm{nmol} / \mathrm{kg} ; P=0.02)$ in stillborn piglets from sows receiving supplements of folic acid during gestation (Table 5).

Table 3. Concentration of folates in colostrum and milk of sows (nmol/l)

(Mean values and standard deviations)

\begin{tabular}{|c|c|c|c|c|c|}
\hline \multirow{2}{*}{ Treatment } & \multirow[b]{2}{*}{$n$} & \multicolumn{2}{|c|}{ Control } & \multicolumn{2}{|c|}{$\begin{array}{l}10 \mathrm{mg} \text { folic } \\
\text { acid } / \mathrm{kg} \mathrm{feed}^{*}\end{array}$} \\
\hline & & Mean & $\overline{S D}$ & Mean & SD \\
\hline $\begin{array}{l}\text { Colostrum } \\
\text { Milk (day } 28 \text { of lactation) }\end{array}$ & $\begin{array}{c}6 \\
15\end{array}$ & $\begin{array}{l}101^{\mathrm{Aa}} \\
30 \cdot 4^{\mathrm{Ab}}\end{array}$ & $\begin{array}{l}55 \cdot 3 \\
29 \cdot 2\end{array}$ & $\begin{array}{l}362^{\mathrm{Ba}} \\
150^{\mathrm{Bb}}\end{array}$ & $\begin{array}{l}131 \\
68 \cdot 4\end{array}$ \\
\hline
\end{tabular}

${ }^{A}, \mathrm{~B}$ Mean values within a row with unlike superscript letters were significantly different $(P<0.05)$.

${ }^{\mathrm{a}, \mathrm{b}}$ Mean values within a column with unlike superscript letters were significantly different $(P<0.05)$.

* Gestation and lactation diet of sows. For details of diets, see p. 180.
Table 4. Concentration of folates in the serum of piglets during the suckling period

(Mean values and standard deviations)

\begin{tabular}{lcccccc}
\hline & & \multicolumn{2}{c}{ Control } & & \multirow{2}{*}{$10 \mathrm{mg}$ folic acid/kg feed* } \\
\cline { 6 - 7 } Treatment & $n$ & Mean & $\mathrm{SD}$ & & Mean & $\mathrm{SD}$ \\
\hline At birth & 18 & $56 \cdot 2^{\mathrm{Aa}}$ & $14 \cdot 7$ & & $92 \cdot 6^{\mathrm{Ba}}$ & $25 \cdot 1$ \\
Day 2 of life & 70 & $175^{\mathrm{Ab}}$ & 87.4 & & $365^{\mathrm{Bb}}$ & 134 \\
Day 14 of life & 76 & $151^{\mathrm{Ab}}$ & $82 \cdot 9$ & & $328^{\mathrm{Bb}}$ & 124 \\
Day 28 of life & 70 & $141^{\mathrm{Ab}}$ & $65 \cdot 2$ & & $281^{\mathrm{Bb}}$ & $81 \cdot 3$ \\
\hline
\end{tabular}

${ }_{\mathrm{A}, \mathrm{B}}$ Mean values within a row with unlike superscript letters were significantly different $(P<0.05)$.

a,b Mean values within a column with unlike superscript letters were significantly different $(P<0.05)$.

* Gestation and lactation diet of sows. For details of diets, see Table 1.

\section{Discussion}

Serum folate status of sows during gestation and lactation In spite of some variations in absolute values, the pattern of decrease in the concentration of serum folates in unsupplemented sows from day 30 to day 60 of gestation was similar to profiles previously reported by Matte et al. (1984, 1992; 1993), Tremblay et al. (1986; 1989), Anzhi \& Cooper (1989), Thaler et al. (1989), O’Connor \& Picciano (1993), Harper et al. (1994), Natsuhori et al. (1996), Fuchs et al. (1996) and Giguère et al. (1999).

Although not significant, the present decrease was numerically important i.e. approximately $25 \%$ (Table 2 ). A decrease of serum folate concentrations during pregnancy was reported in cows, sheep, rats and humans (Ek \& Magnus, 1981; Thenen, 1991; Girard et al. 1996; Girard \& Matte, 1989). As suggested by Matte et al. (1992), such a phenomenon could be due to the metabolic utilisation from the dam for maintenance needs and deposition (products of conception). Changes in renal excretion are unlikely to be involved; Matte \& Girard (1999) did not observe any major changes in urinary renal excretion in gestating sows.

Although all studies mentioned above agree on a decrease of concentration from the beginning to the middle of gestation, discrepancies are reported for the following second half of gestation and the lactation. In agreement with the present results, Matte et al. (1984), Harper et al. (1994) and Natsuhori et al. (1996) observed an almost stable concentration until the end of pregnancy. In contrast, O'Connor \& Picciano (1993) described a small decrease during this period and Matte et al. (1992) as well as Thaler et al. (1989) detected a significant increase of the serum folate concentration.

During lactation, Matte et al. (1992) reported a decrease from farrowing to the 7th day of lactation followed by an

Table 5. Liver folate concentration of stillborn piglets (nmol total folates $/ \mathrm{kg}$ original matter)

\begin{tabular}{llcc}
\hline Treatment & $n$ & Mean & SD \\
\hline Control & 2 & $76 \cdot 3^{\mathrm{b}}$ & $2 \cdot 04$ \\
$10 \mathrm{mg}$ folic acid/kg feed & 5 & $172^{\mathrm{a}}$ & 33.3 \\
\hline
\end{tabular}

${ }^{a, b}$ Mean values within a column with unlike superscript letters were significantly different $(P<0.05)$.

* Gestation and lactation diet of sows. For details of diets, see Table 1. 
increase until the end (day 28) of lactation in gilts. In multiparous sows, the concentration increased during the whole period in studies by Matte \& Girard (1989), O'Connor \& Picciano (1993) and Harper et al. (1994). The present results failed to show any major changes in concentrations from day 100 of gestation to day 28 of lactation. The lack of repeated blood sampling of the sow during lactation in the present experiment did not allow a reliable comparison with profiles of folates reported during lactation in previous studies.

As far as the response to treatments is concerned, an effect was observed only on day 100 of gestation and day 28 of lactation. Such results are different from those reported in early and mid gestation by Tremblay et al. (1986), Thaler et al. (1989), Matte et al. (1992, 1993), Lynch \& Sheehy (1994), Harper et al. (1994) as well as Fuchs et al. (1996), who observed a linear influence of increasing folic acid supplements on the concentration of folates in the serum of sows. The parity does not seem to be involved in explaining the difference from previous results because there was no interaction of the number of parities on the serum concentration in the present study; experimental conditions with only thirty-two sows and basic reproduction performance of the sows (9.25 liveborn piglets and 8.15 weaned piglets per litter) might be a factor to consider.

\section{Folates in colostrum and milk of sows}

The concentration of folates in milk on day 28 of lactation was 2-5 times lower than the corresponding values in colostrum. According to O'Connor et al. (1989), most of the decrease in the concentration of milk folates occurred at the beginning of lactation (day 0-7) There was a further decrease in the concentration up to day 21 of lactation but it was less pronounced than in early lactation. Such a profile was in agreement with Matte \& Girard (1989).

In agreement with the present results, O'Connor et al. (1989) reported, in unsupplemented sows, similar concentration of folates in colostrum $(23.1 \mathrm{nmol} / \mathrm{l})$ and in serum $(24.9 \mathrm{nmol} / \mathrm{l})$ on day 110 of gestation. However, the high colostral concentration as compared with the serum value (day 100 of gestation) in treated sows in the present experiment, suggests a preferential route for supplemental folates towards the colostrum pool. As previously demonstrated by Matte \& Girard (1999) there is no saturation of serum folate at a level of $10 \mathrm{mg}$ folic acid/ $\mathrm{kg}$ feed which supports the theory of a preferential route towards colostrum. In milk, folate concentrations were usually lower than their serum concentrations as also reported by Matte \& Girard (1989), O'Connor et al. (1989) and Matte et al. (1992). However, in treated sows, the effect seen on colostrum persisted, although less markedly, for milk on day 28 of lactation, a phenomenon also shown by Matte et al. (1992).

In sheep, Girard et al. (1996) reported much higher colostrum folate concentrations than in sows (variation between different sheep breeds from 222 to $374 \mathrm{nmol} / \mathrm{l}$ ) and a similar difference of concentrations between colostrum and milk. Nevertheless, folate concentrations of sows' milk seem to be relatively low compared with those in human subjects (152-548 nmol/1; Tamura et al. 1980; Selhub et al. 1984; O'Connor et al. 1991), sheep (164-220 nmol/l; Girard et al. 1996) or cows (134 nmol/1; Girard \& Matte, 1989).

\section{Serum and liver folates of piglets}

As observed by Natsuhori et al. (1996), serum folate concentrations in newborn piglets were much lower before the first intake of colostrum than later during the suckling period. At birth, serum folate concentrations of piglets were about half of those detected in their dams which seems to indicate that the folate transfer 'in utero' is not an active and substantial process. After a sharp increase (4 times) in the serum folate concentration from birth to day 2 of life the concentration seems to drop slightly during the following period of suckling. Such a difference corresponded, in fact, to the changes observed in dams' colostrum and milk. Those results are in agreement with O'Connor et al. (1989) and Natsuhori et al. (1996) but are slightly different from Matte et al. (1992) who reported an increase up to $14 \mathrm{~d}$ of age followed by a gradual decrease towards weaning, on day 28 . Therefore, as suggested by the present change in the ratios between serum folate concentrations in dams and piglets and as reported by Matte et al. (1992), the folate status of the young piglets is more influenced by the postnatal supply of folates from colostrum and milk than by the pre-natal provision.

In agreement with the treatment effects on serum folates of piglets at birth, the results on liver folates indicate that the transfer of folic acid 'in utero', although marginal, can be increased by the supplements of folic acid. However, the present response to treatments in the liver appeared to be much more marked than what was observed earlier in gestation for the whole fetus (Matte et al. 1993) Since there are no data reported on the folate content of livers from newborn piglets until now, our results from a few stillborn piglets can be judged as a first indication for the dependence of the folate carry-over into fetal liver on the folic acid supply of the sow. It should be emphasized again that the amount of liver samples is very limited.

\section{Conclusions}

Folic acid supplements during gestation and lactation influence the carry-over of folates from the sow to the fetus and to the suckling piglet. During the last period of gestation, a significant part of the available folates seems to be directed towards the mammary gland as suggested by the huge amount of folates in the colostrum. Moreover, folic acid supplements induced an intensive transport of folates into colostrum and milk as suggested by the higher concentration of folates in the colostrum and milk as compared to the serum; such transport was not apparent in unsupplemented sows. The priority of folate transport into the mammary gland is critical for the piglet taking into account his relatively low folate status before the first colostrum intake. Therefore, the folate supply for the newborn piglet is dependent mainly upon the carry-over of folates via colostrum and milk. 


\section{References}

Bässler K.-H. (1997) Vitamin-lexicon for physicians, pharmacrits and nutritionists. 2nd ed., Frankfurt (Main): Govi-Verlag, pp. $104-136$

Cerna J \& Kas J (1983) New conception of folacin assay in starch or glycogen containing food samples. Nahrung 27, 957-964.

Dumoulin PG, Girard CL, Matte JJ \& St-Laurent GJ (1991) Effects of parenteral supplement of folic acid and its interaction with level of feed intake on hepatic tissues and growth performance of young dairy heifers. Journal of Animal Science 69, 1657-1666.

Duquette J, Matte JJ, Farmer C, Girard CL \& Laforest J-P (1997) Pre- and post-mating dietary supplements of folic acid and uterin secretory activity in gilts. Canadian Journal of Animal Science 77, 415-420.

Ek J \& Magnus EM (1981) Plasma, red blood cell folate during normal pregnancies. Acta Obstetricia et Gynaecologica Scandinavica 60, 247-251.

Fuchs B, Orda J \& Wilieczkiewicz A (1996) Effect of folic acid supplementation in pregnant sows on the fetal mortality. Medycyna Weterynarya Warschau 52, 293-298.

German Society of Nutrition Physiology (1987) Energy and nutrient requirements of domestic animals. Vol. 4, Pigs 4. Frankfurt (Main): DLG-Verlag.

Giguere et al. (1999) Folic acid, uterus conditioning and control of the reproductive performance of nulliparous sows. Journées de la Recherche Procine en France 31, 33-38.

Girard CL \& Matte JJ (1989) Serum folates in gestating and lactating dairy cows. Journal of Dairy Science 72, 3240-3246.

Girard CL, Castonguay F, Fahmy MH \& Matte JJ (1996) Serum and milk folates during the first two gestations and laktations in Romanov, Finnsheep, and Suffolk ewes. Journal of Animal Science 74, 1711-1715.

Harper AF, Lindemann MD, Chiba LI, Combs GE, Handlin DL, Kornegay ET \& Southern LL (1994) An assessment of dietary folic acid levels during gestation and lactation on reproductive and lactational performance of sows A cooperative study. Journal of Animal Science 72, 2338-2344.

Lynch PB \& Sheehy PJA (1994) Response of breeding sows to long-term dietary supplementation with folic acid. Animal Production 58, 466.

Matte JJ, Farmer C, Girard CL \& Laforest J-P (1996) Dietary folic acid, uterine function and early embryonic development in sows. Canadian Journal of Animal Science 76, 427-433.

Matte JJ \& Girard CL (1989) Effects of intramuscular injections of folic acid during lactation on folates in serum and milk and performance of sows and piglets. Journal of Animal Science 67, 426-431.

Matte JJ \& Girard CL (1999) An estimation of the requirement for folic acid in the gestating sow: The metabolism utilization of folates as a criterion of measurement. Journal of Animal Science 77, 159-165.
Matte JJ, Girard CL \& Brisson GJ (1990) The effect of supplementary folic acid in gestation diets on folates status and reproductive performances of first parity sows. Journal of Animal Science 68, Suppl.1, 370.

Matte JJ, Girard CL \& Brisson GJ (1984) Serum folates during the reproductive cycle of sows. Journal of Animal Science 59, 158163.

Matte JJ, Girard CL \& Brisson GJ (1992) The role of folic acid in the nutrition of gestating and lactating primiparous sows. Livestock Production Science 32, 131-148.

Matte JJ, Girard CL \& Tremblay GF (1993) Effect of long-term addition of folic acid on folate status, growth performance, puberty attainment, and reproductive capacity of sows. Journal of Animal Science 71, 151-157.

National Research Council (1998) Nutrient requirements of swine. 10th, Washington, DC: National Academy Press.

Natsuhori M, Shimoda M \& Kokue E (1996) Alterations of plasma folates in gestating sows and newborn piglets. American Journal of Physiology 270, R99-R104.

O'Connor DL \& Picciano MF (1993) Plasma folate binding capacity of the reproducing pig. Journal of Nutritional Biochemistry 4, 482-487.

O'Connor DL, Picciano MF, Roos MA \& Easter RA (1989) Iron and folate utilization in reproducing swine and their progeny. Journal of Nutrition 119, 1984-1991.

O'Connor DL, Tamura T \& Picciano MF (1991) Pteroylpolyglutamates in human milk. American Journal of Clinical Nutrition 53, 930-934.

Rothenberg SP, da Costa M, Lawson J \& Rosenberg Z (1974) The determination of erythrocyte folate concentration using a twophase ligand-binding radioassay. Blood 43, 437-443.

Selhub J, Arnold R, Smith AM \& Picciano MF (1984) Milk folate protein (FBP) A secretory protein for folate. Nutrition Research 4, 181-187.

German Society of Nutrition Physiology (1987) Energy and nutrient requirements of domestic animals. Vol. 4, Pigs 4. Frankfurt (Main): DLG-Verlag.

Tamura T, Yoshimura Y \& Arakawa T (1980) Human milk folate and folate status in lactating mothers and their infants. American Journal of Clinical Nutrition 33, 193-197.

Thaler RC, Nelssen JL, Goodband RD \& Alle GL (1989) Effect of dietary folic acid supplementation on sow performance through two parities. Journal of Animal Science 67, 3360-3369.

Thenen SW (1991) Gestational, and neonatal folate deficieny in rats. Nutrition Research 11, 105-116.

Tremblay GF, Matte JJ, Girard CL \& Brisson GJ (1989) Serum zinc, iron and copper status during early gestation in sows fed a folic acid-supplemented diet. Journal of Animal Science 67, 733-737.

Tremblay GF, Matte JJ, Lemieux L \& Brisson GJ (1986) Serum folates in gestating swine after folic acid addition to diet. Journal of Animal Science 63, 1173-1178. 